\section{Stem-cell treatments for spinal-cord injury may be worth the risk}

SIR — In his Correspondence 'Caution urged in trial of stem cells to treat spinal-cord injury' (Nature 458, 29; 2009), Yves Barde questions the wisdom of testing oligodendrocyte precursors derived from embryonic stem (ES) cells in patients, despite the promise that such cells hold for repairing these injuries in rodents.

After traumatic injury to the spinal cord, the axons adjacent to the lesion often remain intact but become demyelinated (J. Silver and J. H. Miller Nature Rev. Neurosci. 5, 146-156; 2004). Stem cells derived from adult or embryonic sources can remyelinate denuded axons and restore limited, but significant, recovery of function (see, for example, M. Sasaki et al. Prog. Brain Res. 161, 419-433; 2007). It is therefore plausible that treatment with oligodendrocyte precursors might perform similarly in humans.

I concede Barde's point that there are other issues to consider in developing a comprehensive treatment for paralysis, including axon regeneration, axon-growth inhibitors and the lesion scar. But even partial restoration of function through remyelination would yield valuable improvements in patients, including an ability to breathe independently, enhancement of hand dexterity, recovery of sexual function and restoration of bowel and bladder control.

There is evidence for some degree of recovery from spinalcord injury in animals after experimental cell transplantation alone, or in combination with other agents. But as the rest of the world moves forwards in developing human treatments in this area, the United States lags behind. Given the severity of such injuries and the often-overlooked fact that a patient's condition deteriorates steadily over time, a calculated degree of risk may be justified in pioneering clinical efforts to resolve the dilemma of lifelong paralysis.

People from the United States with spinal-cord injuries are flocking to clinics around the globe for cell transplantations - despite warnings from the scientific and medical communites about the potential dangers - largely because of the paucity of treatment options at home. The US Food and Drug Administration's forthcoming safety trial using ES cells in humans with spinal-cord injuries (see Nature 457, 516; 2009) is therefore a long-awaited and welcome first step.

Jesse Owens Biomedical Program, University of Alaska, Anchorage, Alaska 99508, USA e-mail:afjlo@uaa.alaska.edu

\section{A lesson or two from a regional economic argument}

SIR — In his Commentary on how to survive the recession, 'Work for the greater good' (Nature 457, 959-960; 2009), Eric Rauchway discusses the role that science and technology had in improving living conditions in the Tennessee Valley in the 1930s. As a former staff historian for the Tennessee Valley Authority (TVA), I would like to highlight factors debated then that could still be pertinent today.

As Rauchway tells us, the innovative agricultural reform measures led by Harcourt Morgan helped to restore economic and environmental health to a segment of the country that had suffered for decades, long before the Depression. But there was controversy over the place of science and technology within the TVA's reform agenda, particularly between the other two TVA board members: David Lilienthal, a lawyer who had served on the Wisconsin public service commission, and Arthur Morgan (no relation to Harcourt), an engineer who had been president of Antioch College in Yellow Springs, Ohio.
For Lilienthal, the TVA's mandates for flood control and resource conservation were secondary to one thing: power generation. Only a small percentage of the valley's rural population had access to electric power, and Lilienthal wanted the TVA to produce cheap and reliable electricity to put an end to poverty in the region. Arthur Morgan had even bigger plans: he wanted science to take a back seat and the TVA to be a regional planning agency, with a focus on social and economic reforms, including alternative land-use schemes to encourage the growth of small villages and ensure longterm conservation of resources.

This conflict undermined the TVA's ability to function effectively and, in 1938, President Franklin Roosevelt dismissed Arthur Morgan. The president's decision sealed the agency's fate as an institution primarily focused on electric-power production and distribution. Today, the agency's other responsibilities are dwarfed by the management of its US\$9-billion power system.

But 2009 is not like 1929 (at least, not yet), President Barack Obama's recovery plan is not the New Deal, and no broadband valley authority is destined to do for high-speed Internet connections what the TVA did for access to electricity. However, there are parallels between the debates that surrounded the TVA and those now taking place in Washington DC. What role should the public sector have in the nation's economic-recovery efforts? Should government policies be directed towards getting the economy back on its feet, towards radically changing its direction, or both? Do solutions lie in politically free applications of science and technology? Or should a new social vision determine how - and to what extent - science and technology are applied to realize these goals?

The bankers and modellers who thought that they could vanquish history through the use of the latest financial instruments have failed us miserably. The past has returned with a vengeance. Experiences such as those of the TVA can teach us a thing or two about how to move ahead responsibly in the face of today's global financial crisis.

Daniel Schaffer Sesto al Reghena, Italy e-mail:ddschaffer@yahoo.com

\section{Romanian funding cuts call for more stringent criteria}

SIR - The Lisbon summit in 2000 persuaded many governments that it was in the interest of Europe's long-term economic growth to restore priorities in science and research expenditure; this would also help found the next generation of researchers, innovators and technicians. But these laudable aims are being undermined by the current economic crisis, which disproportionately affects the Eastern European economies.

Despite generous support for all branches of science in the two years leading up to Romania's accession to the European Union in 2007, the latest financial situation is impeding progress just as it was starting to gather momentum. The research budget for this year has been cut back to about $40 \%$ of what it was in 2008. Successful projects that won funding last year are slowing to a halt, along with the ascent of academia and industry.

But it is not just a matter of curbed expenditure. Science lobbyists and policy-makers should have used the financial crisis as an opportunity to apply more stringent funding criteria to raise the quality of scientific output and accelerate progress. Romania cannot actively compete in today's scientific and economic arenas without stimulating scientific creativity.

Tudor Luchian Laboratory of Biophysics and Medical Physics, Department of Physics, Alexandru I. Cuza University, lasi, 700506, Romania

e-mail: luchian@uaic.ro 